\title{
Chemical Composiiton Analysis of INEEL Phase 3 Glasses: Task Technical and QA Plan
}

by

D. Peeler

Westinghouse Savannah River Company

Savannah River Site

Aiken, South Carolina 29808

T. B. Edwards

D. R. Best

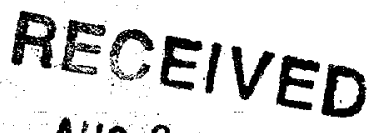

A 166212000

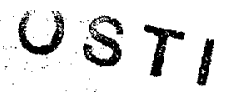

This paper was prepared in connection with work done under the above contract number with the $U$. S.

Department of Energy. By acceptance of this paper, the publisher and/or recipient acknowledges the U. S. Government's right to retain a nonexclusive, royalty-free license in and to any copyright covering this paper, along with the right to reproduce and to authorize others to reproduce all or part of the copyrighted paper. 


\section{DISCLAIMER}

This report was prepared as an account of work sponsored by an agency of the United States Government. Neither the United States Government nor any agency thereof, nor any of their employees, makes any warranty, express or implied, or assumes any legal liability or responsibility for the accuracy, completeness, or usefulness of any information, apparatus, product or process disclosed, or represents that its use would not infringe privately owned rights. Reference herein to any specific commercial product, process or service by trade name, trademark, manufacturer, or otherwise does not necessarily constitute or imply its endorsement, recommendation, or favoring by the United States Government or any agency thereof. The views and opinions of authors expressed herein do not necessarily state or reflect those of the United States Government or any agency thereof.

This report has been reproduced directly from the best available copy.

Available for sale to the public, in paper, from: U.S. Department of Commerce, National Technical Information Service, 5285 Port Royal Road, Springfield, VA 22161

phone: (800) 553-6847

fax: (703) 605-6900

email: orders@ntis.fedworld.gov

online ordering: http://www.ntis.gov/ordering.htm

Available electronically at http://www.doe.gov/bridge

Available for a processing fee to U.S. Department of Energy and its contractors, in paper, from: U.S. Department of Energy, Office of Scientific and Technical Information, P.O. Box 62, Oak Ridge, TN 37831-0062

phone: (865)576-8401

fax: (865)576-5728

email: reports@adonis.osti.gov 


\section{DISCLAIMER}

Portions of this document may be illegible in electronic image products. Images are produced from the best available original document. 


\title{
CHEMICAL COMPOSITION ANALYSIS OF INEEL PHASE 3 GLASSES
}

Task Technical \& QA Plan

\author{
D.K. Peeler, T.B. Edwards, and D.R. Best
}

Westinghouse Savannah River Company

Savannah River Technology Center

Westinghouse Savannah River Company

Savannah River Technology Center

Aiken, SC 29808

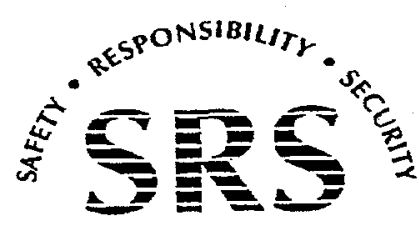

SAVANNAH RIVER SITE

PREPARED FOR THE U.S. DEPARTMENT OF ENERGY UNDER CONTRACT NO. DE-AC09-96SR18500 


\begin{tabular}{|c|c|c|c|}
\hline $\begin{array}{l}\text { Task Title: } \\
\text { Chemical Composition Analysis of INEEL Phase } 3 \\
\text { Glasses }\end{array}$ & & $\begin{array}{l}\text { INEEL IWO: } \\
\text { SR800003 }\end{array}$ & $\begin{array}{l}\text { IWO Date: } \\
\text { Feb. } 2000\end{array}$ \\
\hline $\begin{array}{l}\text { Task Lead: } \\
\text { D.K. Peeler }\end{array}$ & Wignatye: Voedes & $\begin{array}{l}\text { Organization: } \\
\text { ITS }\end{array}$ & Date: 100 \\
\hline $\begin{array}{l}\text { Statistical Task Lead: } \\
\text { T.B. Edwards }\end{array}$ & Sigrature: $B$ Sduarde & $\begin{array}{l}\text { Organization: } \\
\text { SCS }\end{array}$ & Date: $1 / 20 / 00$ \\
\hline $\begin{array}{l}\text { Analytical Task Lead: } \\
\text { D.R. Best }\end{array}$ & Signature / / Bst & $\begin{array}{l}\text { Organization: } \\
\text { ITS } \\
\end{array}$ & $\begin{array}{l}\text { Dake: } \\
7 / 23 / 00\end{array}$ \\
\hline $\begin{array}{l}\text { Technical Reviewer: } \\
\text { A.D. Cozzi }\end{array}$ & Signature: & $\begin{array}{l}\text { Organization: } \\
\text { ITS }\end{array}$ & Date: $1 / 2660$ \\
\hline $\begin{array}{l}\text { Technical Reviewer: } \\
\text { T.H. Lorier }\end{array}$ & Signature: & $\begin{array}{l}\text { Organization: } \\
\text { ITS }\end{array}$ & $\begin{array}{l}\text { Date: } \\
7 / 26 / 2000\end{array}$ \\
\hline $\begin{array}{l}\text { Technical Reviewer: } \\
\text { R.A. Baker }\end{array}$ & Signaturgof & $\begin{array}{l}\text { Organization: } \\
\text { SCS }\end{array}$ & Date: \\
\hline $\begin{array}{l}\text { Manager, Glass Formulation and Melter Technology } \\
\text { D.A. Crowley }\end{array}$ & Signaturi: C. Conley & $\begin{array}{l}\text { Organization: } \\
\text { ITS }\end{array}$ & $\begin{array}{l}\text { Date: } \\
7 / 25 / 00\end{array}$ \\
\hline $\begin{array}{l}\text { Manager, Process Chemistry and Control } \\
\text { S.L. Marra }\end{array}$ & $\begin{array}{l}\text { Signature: } \\
\text { Shavan }\end{array}$ & $\begin{array}{l}\text { Organization: } \quad-- \\
\text { ITS }\end{array}$ & $\begin{array}{l}\text { Date: } \\
7 / 25 / 00 \\
\end{array}$ \\
\hline $\begin{array}{l}\text { Manager, Statistical Consulting Section } \\
\text { R.C. Tuckfield }\end{array}$ & 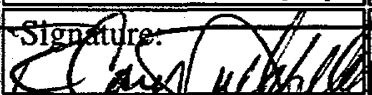 & $\begin{array}{l}\text { Organization: } \\
\text { SCS }\end{array}$ & Date: $7 / 2 \div$ \\
\hline $\begin{array}{l}\text { ITS QA Coordinator: } \\
\text { T.K. Snyder }\end{array}$ & Signatated & $\begin{array}{l}\text { Organization: } \\
\text { KS }\end{array}$ & Datak 100 \\
\hline $\begin{array}{l}\text { SRTC QA Representative: } \\
\text { J.J. Connelly }\end{array}$ & Signature: & $\begin{array}{l}\text { Organization: } \\
\text { SRTC QAD }\end{array}$ & $\begin{array}{l}\text { Date: } \\
\text { OI Aug } 00\end{array}$ \\
\hline
\end{tabular}

\section{DISTRIBUTION:}

\section{SRTC}

R. A. Baker, 773-42A

D. R. Best, 773-41A

K. G. Brown, 704-1T

A. D. Cozzi, 773-43A

D. A. Crowley, 773-43A

J. J. Connelly, 773-42A

T. B. Edwards, 773-42A

E. W. Holtzscheiter, 773-A

T. H. Lorier, 704-1T

S. L. Marra, 704-T

D. K. Peeler, 773-43A

R. H. Spires, 773-A

R. C. Tuckfield, 773-42A
PNNL

J. D. Vienna, K6-24

J. V. Crum, K6-24
INEEL

C. A. Musick, MS-5218

R. R. Kimmitt, MS-5218

B. A. Scholes, MS-5218 


\begin{tabular}{|c|l|l|l|}
\hline $\begin{array}{c}\text { Revision } \\
\text { Number: }\end{array}$ & Page Number: & Date: & Revision: \\
0 & & & \\
\hline
\end{tabular}




\section{INTRODUCTION}

For about four decades radioactive wastes have been collected and calcined from nuclear fuels reprocessing at the Idaho Chemical Processing Plant (ICPP). Over this time span, secondary radioactive waste from decontamination, laboratory activities and fuels storage activities have also been collected and stored as liquid. These liquid high-activity wastes (HAW) are collectively called Sodium Bearing Wastes (SBW). Currently about 5.7 million liters of these wastes are temporarily stored in stainless steel tanks at the Idaho National Engineering and Environmental Laboratory (INEEL). Vitrification is being considered as a treatment option for SBW. The resulting glass can be sent to either the Waste Isolation Pilot Plant (WIPP) near Carlsbad, New Mexico, as remote handled transuranic waste (RH-TRU) or to the federal geologic repository for final disposal. In addition to the SBW, roughly $4,000 \mathrm{~m}^{3}$ of calcined high-level wastes (HLW) are currently being stored at INEEL in stainless steel bin sets. These calcined HLW may also be vitrified, either with or without a dissolution and separation process, and sent to the federal geologic repository for final disposal [1].

The Batt Settlement Agreement was established in August 1995, between the U.S. Navy, the State of Idaho and the U.S. Department of Energy (DOE) [2]. Section E.6 of the Agreement states that all HLW stored at the INEEL will be rendered ready (immobilized) for transport to a suitable repository by the end of year 2035. More immediately, the technology must be applied to provide information needed for design of the HLW treatment facility targeted to begin in the year 2007. This design supports the Settlement Agreement milestone of submitting a Resource Conservation and Recovery Act (RCRA) Part B permit application in year 2012 and the Site Treatment Plan operational date of September 30, 2019.

The Tanks Focus Area (TFA) is sponsoring a partnership among INEEL, Pacific Northwest National Laboratory (PNNL), and the Savannah River Technology Center (SRTC) for a collaborative (phased) glass composition variation study of this waste immobilization option. The purpose of the Composition Variation Study (CVS) is to investigate composition - property relationships within a glass composition region compatible with the expected range of Idaho Nuclear Technology and Engineering Center (INTEC) HAW. The phased approach allows INEEL, PNNL, and SRTC researchers to make adjustments to the compositional envelope as waste stream compositions become more defined and/or as separations processes are refined. In the development of the vitrification process, direct evidence is needed to demonstrate that the separated HAW product can be converted to a vitrified form. Thus, the initial goal of this program is to provide feedback into the developing separations process while establishing a database for composition / property relationships within a glass composition region compatible with the expected range of INEEL HAW resulting from the separations process. The objective of this TFA task is two-fold: (1) develop glass property data and glass composition-property models that cover the expected composition region from individual or blended INEEL HAW's, and (2) support INEEL with glass formulation and testing expertise to assist in flow sheet optimization and melter demonstrations. Efforts related to the development of glass property data and models are described by Piepel et al. [3], Staples et al. [1], and Edwards et al. [4]. Previous glass formulation activities, focusing on blended INEEL waste and zirconia calcine waste have been reported by Peeler et al. [5], and Vienna et al. $[6,7,8]$.

Phase 1 of this study involved a statistically-designed glass CVS performed for the initial composition region of interest [3]. Phase 1 was developed based on a preliminary separations / pretreatment flowsheet. The results from Phase 1, which were reported by Staples et al. [1], provided important feedback into the developing separations processes. Based on the Phase 1 data, it was apparent that phosphate content in the INTEC HAW has an impact on both the tendency of the resulting glasses to phase separate (i.e., amorphous phase separation or glass-in-glass separation) and on the crystallization behavior upon thermal heat treatment. With $\mathrm{P}_{2} \mathrm{O}_{5}$ being introduced primarily from the separations processes, flowsheet adjustments are being 
evaluated to minimize the addition of $\mathrm{P}_{2} \mathrm{O}_{5}$ and other components that could potentially have a negative impact on waste loading, processability, and/or product performance. With the ongoing review and development of the pretreatment flowsheets, a decision was made to evaluate the potential of "direct" vitrification (i.e., no separations or pretreatment) of the INTEC HAW. Although a larger volume of glass may potentially result from "direct vitrification" relative to vitrification of feeds resulting from separations, direct vitrification does offer some advantages (e.g., pretreatment facilities would not be required). The advantages and disadvantages of direct vitrification versus the separations based flowsheets should be further evaluated.

Based on the latest estimates of the HAW compositions, Phase 2 of the CVS was developed to investigate composition - property relationships within the glass composition region compatible with the expected range of INEEL HAW using a "direct" vitrification flowsheet [4]. Phase 2 had two parts: $2 \mathrm{a}$ and $2 \mathrm{~b}$. Phase $2 \mathrm{a}$ involved a scoping study to gain some insight into the solubility of HLW components that were not considered in the Phase 1 CVS, but are major components in the direct vitrification flowsheet, namely fluoride and calcium. The Phase $2 \mathrm{a}$ tests focused on evaluating the effects of $\mathrm{CaO}$ and $\mathrm{F}^{-}\left(\mathrm{as}_{\mathrm{Ca}}\right.$ ) on three primary glass properties - homogeneity, durability as defined by the Product Consistency Test (PCT) [9] and viscosity. The results from Phase $2 \mathrm{a}$ were then used as input into the development of the larger Phase $2 \mathrm{~b}$ test matrix. Edwards et al. [4] present the glass composition experimental region (GCER) and the statistically designed Phase $2 b$ test matrix following the waste glass development strategy discussed by Piepel et al. [10] and utilized in Piepel et al. [3]. The Phase $2 b$ matrix was developed to primarily cover the calcinebearing waste with the assumption that $1150^{\circ} \mathrm{C}$ would be the nominal melter processing temperature. The results of Phase 2 should also provide valuable feedback into separations process development because four components $\left(\mathrm{P}_{2} \mathrm{O}_{5}, \mathrm{~K}_{2} \mathrm{O}, \mathrm{MoO}_{3}\right.$, and $\left.\mathrm{SrO}\right)$ based on a "second generation pretreatment flowsheet" have also been included at some level. Additional studies will be required to evaluate the effect of these components on the various processing and product performance properties.

New estimated HLW compositions were received in March 1999 [4] and were based on "direct" vitrification (i.e., no pretreatment). The results from this phase of the study, which were reported in [11], led to the development of 30 new glass compositions for Phase 3 of this study. The strategy for selecting these glasses are being documented by Piepel et al. ${ }^{\dagger}$

\section{A. Task Definition}

INEEL has fabricated the Phase 3 glasses that will ultimately be used to evaluate various composition - property relationships. In support of this effort, INEEL has requested that SRTC provide analytical support for measurement of chemical compositions of the as fabricated glasses [12].

\section{B. Customer/Requester}

The customer for this effort is INEEL, and the INEEL liaison for this task is R.R. Kimmitt.

\section{Task Responsibilities}

D.A. Crowley assigned this task to D.K. Peeler who has the responsibility of overseeing the completion of this work. D.K. Peeler will be the task leader and is responsible for the proper administration and completion of this task according to 1Q, QAP 2-3, Control of Research and Development Activities [13] and the SRTC Conduct of Research and Development [14]. The final summary report will be included in this responsibility. 
T.B. Edwards will be the lead on statistical aspects of the task. Responsibilities will include developing the analytical plan to support the compositional measurements and compilation of the measured and target glass compositions.

D.R. Best (SRTC Mobile Laboratory (SRTC-ML)) will be the lead on the analytical aspects of the task. Responsibilities include performing the chemical analyses of the Phase 3 glasses. D.R. Best will be responsible for the proper administration and completion of this task according to $1 \mathrm{Q}, \mathrm{QAP}$ 2-3, Control of Research and Development Activities [13] and the SRTC Conduct of Research and Development [14].

T.K. Snyder and the SRTC Quality Assurance Department will provide QA support.

D. Task Deliverables

The result of this task will be a data packet that provides the results of the chemical composition analyses (elemental raw data and conversion to oxide wt\%). No statistical analyses of the data will be performed other than those associated with the assessment of the quality of the data.

\section{E. Technical Reviewers}

A.D. Cozzi, T.H. Lorier, and R.A. Baker will technically review the data packet developed during this task prior to issuance.

\section{TASK ACCEPTANCE CRITERIA}

The customer will have the opportunity to review the data packet prior to issuance.

\section{TASK ACTIVITIES}

The Phase 3 test matrix includes 30 glasses and provides overlap with both Phase 1 and Phase 2 designs. With the test matrix designed, INEEL will fabricate these glasses using reagent grade oxides and carbonates. Once fabricated, INEEL will supply SRTC all as fabricated glasses. These glasses should be clearly identified using the IG3 nomenclature. SRTC will perform chemical composition measurement on the as fabricated Phase 3 glasses. For quality assurance purposes, the following controls will be in place and enforced:

\section{A. Chemical Composition}

To evaluate whether targeted glass compositions were adequately met, chemical composition of each as fabricated Phase 3 glass will be measured. A representative sample from each Phase 3 glass will be submitted to the SRTC-ML for chemical analysis. An analytical plan (see Appendix A) describing the dissolution techniques to be used and the cations to be analyzed for will be submitted with these samples. SRTC-ML routine analytical procedures will be used. A set of standard glasses will be included as a control with every set of glasses analyzed.

\section{TASK SCHEDULE}

The major unit operations and schedule estimate are provided below:

\author{
Receipt of Glasses \\ Glass Composition Measurement \\ Data Reduction Phase 3 \\ Issue Draft Data Packet for Review \\ Issue Final Data Packet
}

\author{
Complete \\ $7 / 24 / 00-8 / 18 / 00$ \\ $8 / 21 / 00-8 / 23 / 00$ \\ $8 / 25 / 00$ \\ $8 / 30 / 00$
}


Estimated schedule for completion of this task (i.e., issuing final report) is $\sim 6$ weeks from approval of the Task and QA Plan.

\section{RESEARCH FACILITY PLANNING}

The equipment required to complete these tasks are located within SRTC. No by-products will be generated in this task that are not covered by the current waste management and disposal procedures. The test equipment utilized will be maintained during the testing program and the appropriate standards will be used where applicable. All applicable sections of the WSRC Safety Manual [15] will be followed. The safety sections of each procedure employed will be followed.

\section{PROGRAMMATIC RISK REVIEW}

The programmatic risk review evaluated the impacts to costs, schedule and milestones given the occurrence of unexpected delays (e.g., equipment outages, priority, etc). The only task to be completed in this Technical Task and QA plan is the measurement of chemical compositions that will be supported solely by the SRTC-ML. Given that the SRTC-ML could not perform these measurements in support of the $8 / 30 / 00$ milestone, samples can be submitted to Analytical Development Section for analysis. Given this scenario, SRTC's internal schedule may be impacted but there should be no impact to INEEL's 9/30/00 milestone to issue a report on composition - property relationships for the Phase 3 glasses (the chemical compositions are in support of this milestone).

\section{R\&D HAZARDS SCREENING CHECKLIST}

The R\&D Hazards screening checklist has been reviewed and is documented in WSRC-NB-9900235. Procedures to be utilized are contained within Procedure Manual L28, SRTC Mobile Laboratory Procedure Manual.

\section{REFERENCES}

(1) Staples, B. A., D. K. Peeler, J. D. Vienna, B. A. Scholes, and C. A. Musick. 1999. The Preparation and Characterization of INTEC HAW Phase 1 Composition Variation Study Glasses, INEEL/EXT-98-00970, Rev. 1, Idaho National Engineering and Environmental Laboratory, Idaho Falls, Idaho.

(2) US DOE. 1995. The INEEL Spent Nuclear Fuel and Environmental Restoration and Waste Management Programs Environmental Impact Statement. DOE/EIS-0203-F, U.S. Department of Energy, Washington, D.C.

(3) Piepel, G. F., J. D. Vienna, and P. Hrma. 1999. Phase I Experimental Design for the INEEL HLW Glass Composition Variation Study, PNNL-SA-29594, Rev. 2, Pacific Northwest National Laboratory, Richland, Washington.

(4) Edwards, T.B., D.K. Peeler, I.A. Reamer, G.F. Piepel, J.D. Vienna, and H. Li, Phase $2 b$ Experimental Design for the INEEL Glass Composition Variation Study (U), WSRC-TR-9900224, Rev. 0, March 30, 1999.

(5) Peeler, D. K., I. A. Reamer, J. D. Vienna, and J. V. Crum. 1998. Technical Status Report, Preliminary Glass Formulation Report for INEEL HAW, WSRC-TR-98-00132, Rev. 1, Westinghouse Savannah River Company, Aiken, South Carolina.

(6) Vienna, J. D., T.J. Plaisted, R.L. Plaisted, D.K. Peeler, J.V. Crum, R.D. Tillotson, I.A. Reamer, C.A. Musick, and T. James. 1999. Glass Formulation for Idaho National 
Engineering and Environmental Laboratory Zirconia Calcine High-Activity Waste, PNNL12202, Pacific Northwest National Laboratory, Richland, Washington.

(7) Vienna, J. D., D. K. Peeler, T. J. Plaisted, R. L. Plaisted, I. A. Reamer, and J. V. Crum. 2000. Glass Formulation For Idaho National Engineering and Environmental Laboratory Zirconia High-Activity Waste, Ceramic Transactions 107, in press, American Ceramic Society, Westerville, Ohio.

(8) Vienna, J. D., M.J. Schweiger, D.E. Smith, H.D. Smith, J.V. Crum, D. K. Peeler, I.A. Reamer, C.A. Musick, and R.D. Tillotson. 1999. Glass Formulation for INEEL Sodium-Bearing Waste, PNNL-12234, July 1999.

(9) ASTM. 1994. Standard Test Method for Determining Chemical Durability of Nuclear Waste Glasses, The Product Consistency Test (PCT), ASTM-C-1285-94, in Annual Book of ASTM Standards, Vol. 12.01, American Society for Testing \& Materials, Philadelphia, Pennsylvania.

(10) Piepel, G.F., P. Hrma, and J. D. Vienna. 1998. Glass Chemistry Development Strategy For Hanford High Level Waste (HLW), in Science and Technology for Disposal of Radioactive Tank Wastes, Eds, W.W. Schultz and N.J. Lombardo, pp. 393-402, Plenum Press, New York.

(11) Staples, B.A., B.A. Scholes, D.K. Peeler, L.L. Torres, J.D. Vienna, C.A. Musick, and B.R. Boyle. 2000. The Preparation and Characterization of INTEC Phase $2 b$ Composition Variation Study Glasses, INEEL/EXT-99-01322, February 2000.

(12) Painter, G.W., Interoffice Work Order (IWO) No. SR800003 from Idaho Operations Office, Memorandum to William R. Hull, February 7, 2000.

(13) WSRC 1Q Quality Assurance Manual, QAP 2-3, Control of Research and Development Activities (1998).

(14) Conduct of Research \& Development Savannah River Technology Center (U), WSRC-IM-9700024, Rev. 1, November 30, 1998.

(15) Employee Safety Manual, 8Q, (1997). 
IX. QA Plan Checklist

The following QA Procedures apply for this task (indicate Yes, No or "AR" - as required). Current revision of the procedure will be used.

\begin{tabular}{|c|c|c|c|}
\hline Yes & No & $\mathbf{A R}$ & \\
\hline & & & 1.1 ORGANIZATION \\
\hline $\bar{X}$ & & & 1Q, QAP 1-1, Organization \\
\hline \multirow[t]{6}{*}{$\mathbf{X}$} & & & $\mathrm{L} 1,1.02$, SRTC Organization \\
\hline & & & \\
\hline & & & 1-2 STOP WORK \\
\hline & & $\mathbf{X}$ & 1Q, QAP 1-2, Stop Work \\
\hline & & & \\
\hline & & & 2-1 QUALITY ASSURANCE PROGRAM \\
\hline $\mathbf{X}$ & & & 1Q, QAP 2-1, Quality Assurance Program \\
\hline $\bar{x}$ & & & L1, 8.01, SRTC QA Program Implementation \\
\hline \multirow[t]{3}{*}{$\mathbf{X}$} & & & L1, 8.02, SRTC QA Program Clarifications, Attachment 6 \\
\hline & & & \\
\hline & & & 2-2 PERSONNEL TRAINING \& QUALIFICATION \\
\hline $\mathbf{X}$ & & & 1Q, QAP 2-2, Personnel Training \& Qualification \\
\hline $\mathbf{X}$ & & & L1, 5.01, SRTC Training, Orientation \& Employee Development \\
\hline \multirow[t]{3}{*}{$\mathbf{X}$} & & & $\mathrm{L} 1,1.32$, Read and Sign \\
\hline & & & \\
\hline & & & 2-3 CONTROL OF RESEARCH \& DEVELOPMENT ACTIVITIES \\
\hline$\underline{\mathbf{X}}$ & & & 1Q, QAP 2-3, Control of Research \& Development Activities \\
\hline$\underline{\mathbf{X}}$ & & & L1, 8.02, SRTC QA Program Clarifications, Attachment 1 \\
\hline \multirow[t]{9}{*}{$\underline{\mathbf{X}}$} & & & $\mathrm{L} 1,7.10$, Control of Technical Work \\
\hline & & & \\
\hline & $\mathbf{X}$ & & $\begin{array}{l}\text { 2-4 AUDITOR/LEAD AUDITOR QUALIFICATION \& CERTIFICATION - } \\
\text { does not apply to Immobilization Technology Section Tasks }\end{array}$ \\
\hline & & & \\
\hline & $\mathbf{X}$ & & $\begin{array}{l}\text { 2-5 QUALIFICATION \& CERTIFICATION OF INDEPENDENT } \\
\text { INSPECTION PERSONNEL - does not apply to Immobilization Technology } \\
\text { Section Tasks }\end{array}$ \\
\hline & & & \\
\hline & $\mathbf{X}$ & & $\begin{array}{l}\text { 2-6 QA MANUAL REVISION - does not apply to Immobilization Technology } \\
\text { Section Tasks }\end{array}$ \\
\hline & & & \\
\hline & & & $\begin{array}{l}2-7 \text { QA PROGRAM REQUIREMENTS FOR ANALYTICAL } \\
\text { MEASUREMENT SYSTEMS }\end{array}$ \\
\hline \multirow[t]{7}{*}{$\mathbf{X}$} & & & 1Q, QAP 2-7, QA Program Requirements for Analytical Measurement Systems \\
\hline & & & \\
\hline & $\overline{\mathbf{X}}$ & & $\begin{array}{l}\text { 2-10 INDEPENDENT INSPECTION PERSONNEL ON-THE-JOB TRAINING } \\
\text { - does not apply to Immobilization Technology Section }\end{array}$ \\
\hline & & & \\
\hline & & & 3.1 DESIGN CONTROL \\
\hline & $\mathbf{X}$ & & 1Q, QAP 3-1, Design Control \\
\hline & $\mathbf{X}$ & & L1, 7.10, Control of Technical Work \\
\hline
\end{tabular}




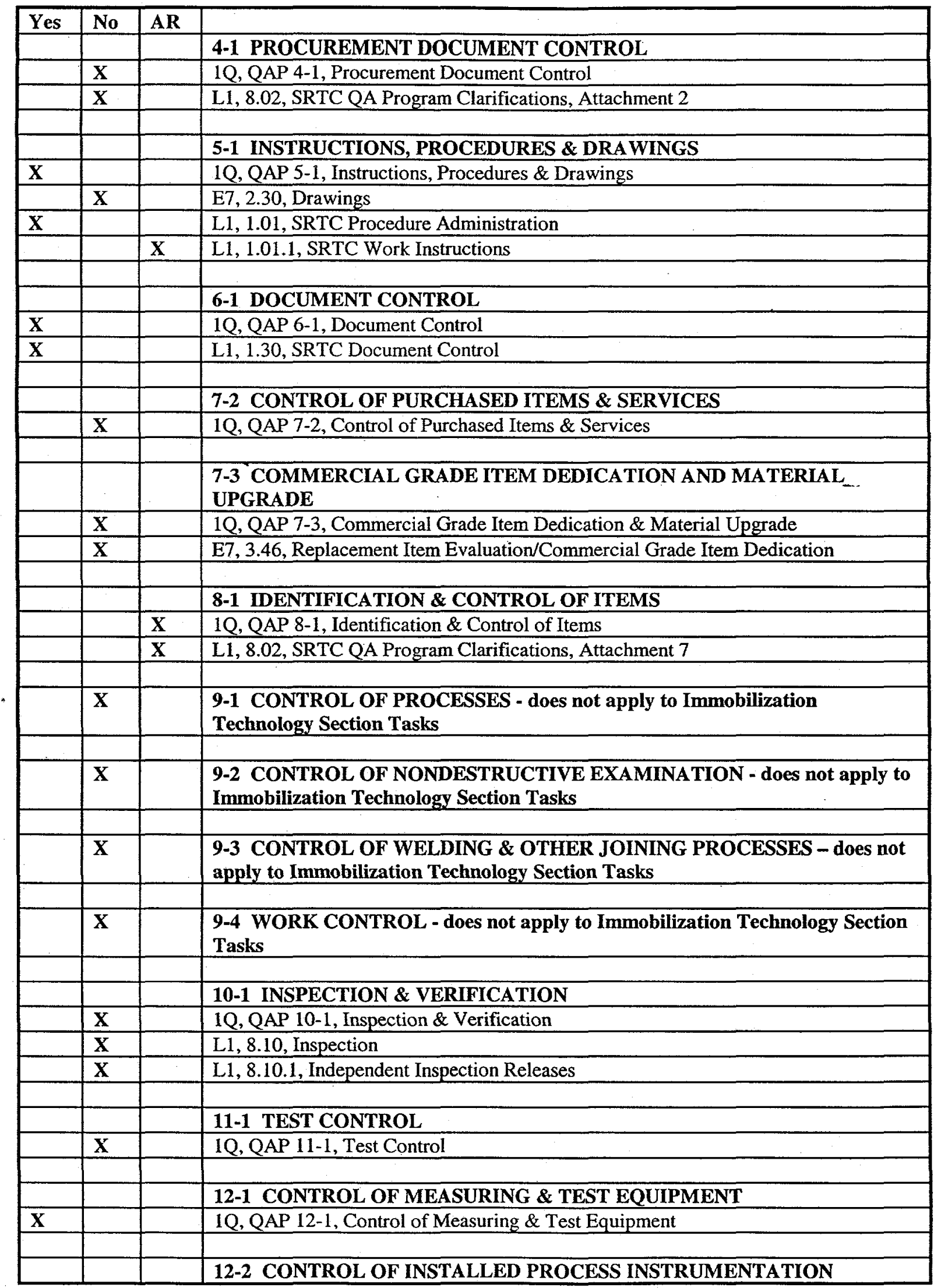




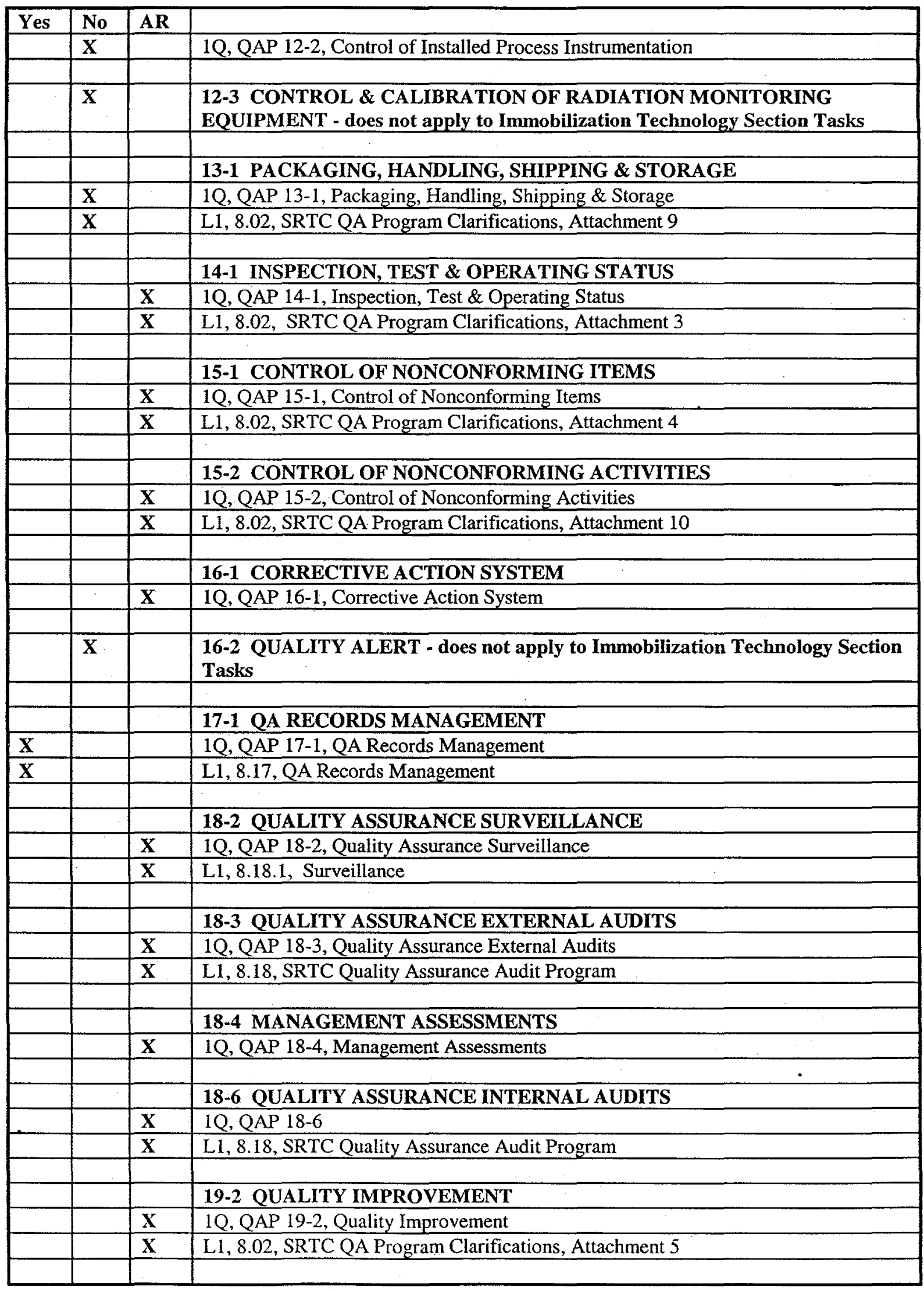




\begin{tabular}{|l|l|l|l|}
\hline Yes & No & AR & \\
\hline & & & 20-1 SOFTWARE QUALITY ASSURANCE \\
\hline & $\mathrm{X}$ & & $1 \mathrm{Q}$, QAP 20-1, Software Quality Assurance \\
\hline & $\mathrm{X}$ & & L1,8.20, Software Management \& Quality Assurance \\
\hline & & & \\
\hline & $\mathrm{X}$ & & $\begin{array}{l}\text { 21-1 ENVIRONMENTAL QUALITY ASSURANCE - does not apply to } \\
\text { Immobilization Technology Section Tasks }\end{array}$ \\
\hline
\end{tabular}

X. Identify any exceptions or additions to the procedures listed in the QA Matrix:

None.

XI. Complete this part only if Section 20 procedures (software) are invoked. Identify who will act in each of the following capacities. N/A

Owner: N/A

Designer: N/A

Maintainer: N/A

Tester: N/A

XII. Document Approval:

Identify documents requiring management, customer or CQF approval

\begin{tabular}{|c|c|c|c|}
\hline Document & Management & Customer & $\mathrm{CQF}$ \\
\hline & Yes $\quad$ No & Yes $\quad$ No & Yes No \\
\hline Technical \& QA Plan & $\mathrm{X}$ & $\mathrm{X}$ & $\mathrm{X}$ \\
\hline Final Report & $\mathrm{X}$ & $\mathrm{X}$ & $\mathrm{X}$ \\
\hline
\end{tabular}

XIII. Anticipated Records:

The following records are anticipated from this task. Indicate Yes, No or AR (as required):

\begin{tabular}{|l|l|l|l|}
\hline \multicolumn{1}{|c|}{ Yes } & No & AR & \\
\hline $\mathrm{X}$ & & & Task Technical \& QA Plan \\
\hline $\mathrm{X}$ & & & Technical Notebooks \\
\hline & & $\mathrm{X}$ & Task Technical Reports \\
\hline & $\mathrm{X}$ & & Data Qualification Reports \\
\hline & & $\mathrm{X}$ & Supporting Documentation \\
\hline
\end{tabular}

Any additional comments:

None

\section{ATTACHMENTS}

Appendix A: Analytical Plan for Measuring Chemical Compositions of INEEL Phase 3 Glasses 
Immobilization Technology Section

WSRC-RP-2000-00683

Rev. 0

Savannah River Technology Center

July 10,2000

Task Technical and QA Plan

July 10,2000

APPENDIX A

Analytical Plan for Measuring Chemical Compositions of INEEL Phase 3 Glasses 
This page intentionally left blank. 


\section{INTRODUCTION}

High-activity waste (HAW), legacy material generated during the reprocessing of nuclear fuel, is being stored at the Idaho Nuclear Technology and Engineering Center (INTEC). The vitrification of this waste using a borosilicate glass system is being evaluated by the Idaho National Engineering and Environmental Laboratory (INEEL) high-level waste (HLW) Technology Development organization. The Tanks Focus Area (TFA) is also supporting this evaluation by sponsoring a partnership among INEEL, Pacific Northwest National Laboratory (PNNL), and the Savannah River Technology Center (SRTC) for a collaborative (phased) glass composition variation study of this waste immobilization option.

A composition variation study (CVS) is underway to investigate composition-property relationships within a glass composition region compatible with the expected range of INEEL HAW. Phase 1 of this study involved a statistically designed glass CVS performed for the initial composition region of interest (i.e., based on initial separations and pretreatment flowsheets) [1]. The results from that study, which were reported in [2], along with updated estimates of the HLW compositions led to the definition of a test matrix for the second phase (Phase 2) of this study [3]. The new estimated HLW compositions were received in March 1999 [3] and were based on "direct" vitrification (i.e., no pretreatment). The results from this phase of the study, which were reported in [4], led to the development of 30 new glasses for Phase 3 of this study.

INEEL has requested analytical support from SRTC in the characterization of the as-fabricated Phase 3 glasses. SRTC has developed a mobile laboratory (ML) capable of conducting compositional (and other critical) analyses on glass samples. This appendix provides an analytical plan for the SRTC-ML to follow in measuring the chemical compositions of the Phase 3 glasses.

\section{Discussion}

The 30 Phase 3 glasses have been designated as IG3-01 through IG3-30. The analytical procedures (L28 Manual, SRTC Mobile Laboratory Procedure Manual) used by the SRTC-ML to determine cation concentrations for a glass sample include steps for sample preparation and for instrument calibration. Each glass is to be prepared in duplicate by each of two dissolution methods: peroxide fusion and lithium metaborate, and a single sample of each glass is to be prepared by potassium hydroxide.

The primary measurements of interest are to be acquired as follows: samples prepared by peroxide fusion are to be analyzed for aluminum ( $\mathrm{Al}$ ), boron $(\mathrm{B})$, calcium $(\mathrm{Ca})$, iron $(\mathrm{Fe})$, potassium $(\mathrm{K})$, lanthium (La), lithium (Li), molybdenum (Mo), nickel (Ni), phosphorous $(\mathrm{P})$, silicon $(\mathrm{Si})$, strontium $(\mathrm{Sr})$, and zirconium $(\mathrm{Zr})$ content. Samples prepared by lithium metaborate are to be analyzed for sodium $(\mathrm{Na})$. Samples dissolved by either of these first two methods are to be analyzed using Inductively Coupled Plasma (ICP) - Atomic Emission Spectrometry (AES). The fluoride (F) and sulfate $\left(\mathrm{SO}_{4}{ }^{-}\right)$contents are to be analyzed using Ion Chromatography (IC) in those samples prepared by the potassium hydroxide fusion.

In addition to these primary constituents of the glass, a constant amount $(\sim 0.5$ weight percent, wt $\%$, of the glass) of an "Others" component was utilized in the batching of each of the INEEL Phase 3 glasses. This "Others" component consisted of the following: $\mathrm{BaO}, \mathrm{CeO}_{2}, \mathrm{Cl}, \mathrm{Cr}_{2} \mathrm{O}_{3}, \mathrm{Cs}_{2} \mathrm{O}, \mathrm{I}, \mathrm{MgO}, \mathrm{MnO}$, $\mathrm{Nb}_{3} \mathrm{O}_{5}, \mathrm{Nd}_{2} \mathrm{O}_{3}, \mathrm{PdO}, \mathrm{Pr}_{2} \mathrm{O}_{3}, \mathrm{Rb}_{2} \mathrm{O}, \mathrm{ReO}_{2}, \mathrm{Rh}_{2} \mathrm{O}_{3}, \mathrm{RuO}_{2}, \mathrm{Sm}_{2} \mathrm{O}_{3}, \mathrm{SnO}_{2}, \mathrm{TeO}_{2}$, and $\mathrm{Y}_{2} \mathrm{O}_{3}$. The SRTC-ML is to measure the concentrations of these components in the INEEL glasses utilizing the prepared samples as described in the previous paragraph. The concentrations of most of these components should be below $0.1 \mathrm{wt} \%$ in the glass, therefore many of these components may yield concentration measurements below detection for these samples.

Randomizing the preparation steps and blocking and randomizing the measurements for each instrument (e.g., ICP and IC) is of primary concern in the development of this analytical plan. The sources of uncertainty for the analytical procedure used by the SRTC-ML to determine the cation and 

anion concentrations for the Phase 3 glasses primarily involve the dissolution step in the preparation of the sample and the calibrations of the two instruments involved. These procedural steps are of primary concern in the development of this analytical plan.

Samples of a standard glass will be included in the analytical plan to provide an opportunity for checking the performance of the instrumentation over the course of these analyses and for potential bias-correction. Specifically, several samples of LRM, a borosilicate reference glass for the Hanford Low Activity Waste program, are also included in this plan.

\section{Analytical Plan}

Each glass sample submitted to the SRTC-ML will be prepared in duplicate by each of the two dissolution methods, and the prepared samples will be read twice by ICP-AES, with the instrument being calibrated before each of these two sets of readings. Each glass sample submitted to the SRTCML will also be prepared once using the potassium hydroxide method, and the prepared samples will be read twice by IC, with the instrument being calibrated before each of these two sets of readings. This will lead to four measurements for each cation and anion (fluoride and sulfate) of interest in each submitted glass sample.

The analytical plan is provided in this section. Table 1 presents identifying codes, H01 through $\mathrm{H} 30$, for the 30 glasses batched as part of Phase 3 . This provides a naming convention that is to be used in analyzing these glasses and reporting the measurements of their compositions. ${ }^{1}$

Table 1: Identifiers to Establish Blind Samples for SRTC-ML.

\begin{tabular}{|cc|cc|}
\hline INEEL ID & SRTC-ML ID & INEEL W & SRTC-ML D \\
IG3-01 & H23 & IG3-16 & H22 \\
IG3-02 & H30 & IG3-17 & H09 \\
IG3-03 & H15 & IG3-18 & H18 \\
IG3-04 & H29 & IG3-19 & H01 \\
IG3-05 & H25 & IG3-20 & H13 \\
IG3-06 & H14 & IG3-21 & H04 \\
IG3-07 & H05 & IG3-22 & H02 \\
IG3-08 & H28 & IG3-23 & H03 \\
IG3-09 & H21 & IG3-24 & H10 \\
IG3-10 & H24 & IG3-25 & H06 \\
IG3-11 & H20 & IG3-26 & H26 \\
IG3-12 & H12 & IG3-27 & H07 \\
IG3-13 & H19 & IG3-28 & H08 \\
IG3-14 & H27 & IG3-29 & H16 \\
IG3-15 & H17 & IG3-30 & H11 \\
\hline
\end{tabular}

\section{PREPARATION OF THE SAMPLES}

Each of the 30 glasses included in this analytical plan, with labels between $\mathrm{H} 01$ and $\mathrm{H} 30$, is to be prepared in duplicate by each of the two dissolution methods: peroxide fusion and lithium metaborate, and a single sample of each glass is to be prepared using potassium hydroxide. Table 2 provides a (random) sequencing scheme for conducting this step of the analytical procedures and identifiers for the samples that indicate the preparation method and number.

1 Renaming these samples helps to ensure that they will be processed as blind samples within the SRTC-ML. 
Table 2: Randomized Preparation Blocks.

\begin{tabular}{|c|c|c|c|c|c|c|c|c|c|}
\hline \multicolumn{4}{|c|}{$\begin{array}{l}\text { Peroxide Fusion (pf) } \\
\text { Dissolution Method }\end{array}$} & \multicolumn{4}{|c|}{$\begin{array}{c}\text { Lithium Metaborate Flux (mb) } \\
\text { Dissolution Method }\end{array}$} & \multicolumn{2}{|c|}{$\begin{array}{l}\text { Potassium Hydroxide (kh) } \\
\text { Dissolution Method }\end{array}$} \\
\hline 1 & 2 & 3 & 4 & 1 & 2 & 3 & 4 & 1 & 2 \\
\hline H3Opf1 & H09pf1 & H17pf1 & H04pf1 & $\mathrm{H} 28 \mathrm{mbl}$ & $\mathrm{H} 16 \mathrm{mbl}$ & $\mathrm{H} 22 \mathrm{mbl}$ & $\mathrm{H} 05 \mathrm{mb} 1$ & H07kh1 & H30kh1 \\
\hline H21pf1 & $\mathrm{H} 29 \mathrm{pfl}$ & H16pf1 & H07pf1 & H07mbl & H01mb1 & $\mathrm{H} 04 \mathrm{mb} 1$ & $\mathrm{H} 27 \mathrm{mb} 1$ & H02kh1 & H23kh 1 \\
\hline H22pf1 & $\mathrm{H} 24 \mathrm{pf} 1$ & H08pf1 & H28pf1 & H09mb1 & $\mathrm{H} 03 \mathrm{mb} 1$ & $\mathrm{H} 02 \mathrm{mb} 1$ & $\mathrm{H} 10 \mathrm{mb} 1$ & H19kh1 & H17kh1 \\
\hline $\mathrm{H} 27 \mathrm{pfl}$ & H20pf1 & $\mathrm{H} 16 \mathrm{pf} 2$ & H01pf1 & H30mb1 & H12mb1 & $\mathrm{H} 22 \mathrm{mb} 2$ & H06mb1 & H15kh1 & H04kh1 \\
\hline H15pf1 & $\mathrm{H} 29 \mathrm{pf} 2$ & H06pf1 & H28pf2 & H09mb2 & H21 mb1 & $\mathrm{H} 17 \mathrm{mbl}$ & $\mathrm{H} 27 \mathrm{mb} 2$ & H24kh1 & H21kh 1 \\
\hline H21pf2 & H24pf2 & H12pf1 & H02pf1 & $\mathrm{H} 28 \mathrm{mb} 2$ & $\mathrm{H} 18 \mathrm{mb} 1$ & $\mathrm{H} 26 \mathrm{mb} 1$ & H05mb2 & H26kh1 & H06kh1 \\
\hline H15pf2 & H05pfl & H13pf1 & H18pf1 & H29mb1 & $\mathrm{H} 03 \mathrm{mb} 2$ & $\mathrm{H} 24 \mathrm{mb} 1$ & $\mathrm{H} 25 \mathrm{mb} 1$ & H03kh1 & H25kh1 \\
\hline H30pf2 & H20pf2 & H26pf1 & H04pf2 & H20mb1 & $\mathrm{H} 21 \mathrm{mb} 2$ & $\mathrm{H} 17 \mathrm{mb} 2$ & $\mathrm{H} 13 \mathrm{mb} 1$ & $\mathrm{H} 22 \mathrm{kh} 1$ & H18khI \\
\hline $\mathrm{H} 27 \mathrm{pf} 2$ & H14pfl & H03pfl & H02pf2 & $\mathrm{H} 29 \mathrm{mb} 2$ & $\mathrm{H} 16 \mathrm{mb} 2$ & $\mathrm{H} 04 \mathrm{mb} 2$ & H13mb2 & H10kh1 & H11kh1 \\
\hline H10pf1 & H23pfl & H06pf2 & H1 1pf1 & $\mathrm{H} 20 \mathrm{mb} 2$ & $\mathrm{H} 14 \mathrm{mbl}$ & $\mathrm{H} 26 \mathrm{mb} 2$ & H10mb2 & H09kh1 & H14kh1 \\
\hline $\mathrm{H} 22 \mathrm{pf} 2$ & H19pfl & $\mathrm{H} 17 \mathrm{pf} 2$ & H18pf2 & H30mb2 & $\mathrm{H} 01 \mathrm{mb} 2$ & H02mb2 & $\mathrm{H} 06 \mathrm{mb} 2$ & H16kh1 & H29kh1 \\
\hline H10pf2 & H19pf2 & H03pf2 & H01pf2 & H08mb1 & $\mathrm{H} 23 \mathrm{mb} 1$ & $\mathrm{H} 11 \mathrm{mb} 1$ & $\mathrm{H} 25 \mathrm{mb} 2$ & H20kh1 & H01kh1 \\
\hline H25pf1 & H05pf 2 & H13pf2 & H07pf2 & $\mathrm{H} 15 \mathrm{mb} 1$ & $\mathrm{H} 12 \mathrm{mb} 2$ & $\mathrm{H} 24 \mathrm{mb} 2$ & H19mb1 & H05kh1 & H12kh1 \\
\hline $\mathrm{H} 25 \mathrm{pf} 2$ & H14pf2 & H12pf2 & H11pf2 & H08mb2 & $\mathrm{H} 23 \mathrm{mb} 2$ & $\mathrm{H} 11 \mathrm{mb} 2$ & H19mb2 & H13kh1 & H08kh1 \\
\hline & H23pf2 & H08pf2 & & H15mb2 & $\mathrm{H} 14 \mathrm{mb} 2$ & & & H27kh1 & H28kh1 \\
\hline & H09pf2 & $\mathrm{H} 26 \mathrm{pf} 2$ & & $\mathrm{H} 07 \mathrm{mb} 2$ & $\mathrm{H} 18 \mathrm{mb} 2$ & & & & \\
\hline
\end{tabular}

Four blocks of preparation work are provided for each preparation method to facilitate the scheduling of these activities by work shift. The identifier for each of the prepared samples presented in Table 2 has been modified to indicate the preparation method used and the duplicate number. Since there are 30 glasses being prepared in duplicate by each of two methods and once by an additional method, the total number of prepared glass samples is determined by $(30 \times 2 \times 2)+30=150$, not including the samples of the LRM glass standard. The preparation of this standard glass is to be conducted by each method using amounts sufficient to provide the necessary samples for each of the ICP and IC blocks discussed below.

\section{ICP Calibration Blocks}

The glass samples prepared by the peroxide fusion and lithium metaborate dissolution methods are to be analyzed using ICP instrumentation calibrated for the particular preparation method. After the initial set of cation concentration measurements, the ICP instrumentation is to be recalibrated and a second set of concentration measurements for the cations determined. A (randomized) plan for measuring cation concentrations in the prepared samples by each dissolution method is provided in Tables 3-4.

In these tables, the sample identifiers for the 30 glasses have been modified by the addition of a suffix (a "1" or a "2") to indicate whether the measurement was made during the first or second (respectively) ICP calibration block. Samples of the LRM standard glass, prepared using the appropriate dissolution method, have been added to each of these tables. The identifiers for these samples begin with the letter "s" followed by the 2-letter dissolution indicator, then the two-digit ICP block identifier, and finally, a number 1 through 3 for the three replicates. 
Table 3: ICP Blocks for the Cation Measurements

Using Peroxide Fusion (pf) Preparation Method.

\begin{tabular}{|cc|cc|cc|cc|}
\hline $1-1$ & $1-2$ & $2-1$ & $2-2$ & $3-1$ & $3-2$ & $4-1$ & $4-2$ \\
spf111 & spf121 & spf211 & spf221 & spf311 & spf321 & spf411 & spf421 \\
H25pf11 & H27pf22 & H14pf11 & H14pf12 & H03pf21 & H26pf22 & H07pf21 & H07pf22 \\
H10pf11 & H21pf12 & H05pf21 & H24pf12 & H03pf11 & H26pf12 & H02pf21 & H04pf22 \\
H30pf11 & H30pf12 & H29pf11 & H19pf12 & H16pf21 & H12pf12 & H02pf11 & H18pf12 \\
H15pf21 & H15pf12 & H19pf11 & H09pf12 & H16pf11 & H13pf12 & H28pf11 & H11pf22 \\
H22pf11 & H22pf12 & H09pf21 & H29pf12 & H08pf21 & H13pf22 & H01pf11 & H02pf12 \\
H25pf21 & H22pf22 & H24pf11 & H23pf12 & H08pf11 & H16pf12 & H04pf21 & H28pf12 \\
H30pf21 & H10pf12 & H20pf21 & H29pf22 & H12pf11 & H16pf22 & H28pf21 & spf422 \\
spf112 & spf122 & H20pf11 & H14pf22 & H12pf21 & H03pf12 & spf412 & H04pf12 \\
H27pf21 & H15pf22 & spf212 & spf222 & spf312 & spf322 & H04pf11 & H07pf12 \\
H10pf21 & H25pf12 & H19pf21 & H24pf22 & H26pf11 & H08pf12 & H11pf21 & H02pf22 \\
H27pf11 & H30pf22 & H14pf21 & H23pf22 & H06pf21 & H03pf22 & H01pf21 & H01pf12 \\
H15pf11 & H21pf22 & H29pf21 & H20pf22 & H26pf21 & H17pf12 & H11pf11 & H11pf12 \\
H21pf21 & H27pf12 & H23pf11 & H09pf22 & H17pf11 & H17pf22 & H18pf21 & H28pf22 \\
H21pf11 & H10pf22 & H05pf11 & H19pf22 & H06pf11 & H12pf22 & H18pf11 & H01pf22 \\
H22pf21 & H25pf22 & H23pf21 & H05pf12 & H13pf11 & H06pf22 & H07pf11 & H18pf22 \\
spf113 & spf123 & H09pf11 & H20pf12 & H13pf21 & H06pf12 & spf413 & spf423 \\
& & H24pf21 & H05pf22 & H17pf21 & H08pf22 & & \\
spf313 & spf323 & & \\
\hline
\end{tabular}

Table 4: ICP Blocks for Cation Measurements Using Lithium Metaborate (mb) Preparation Method.

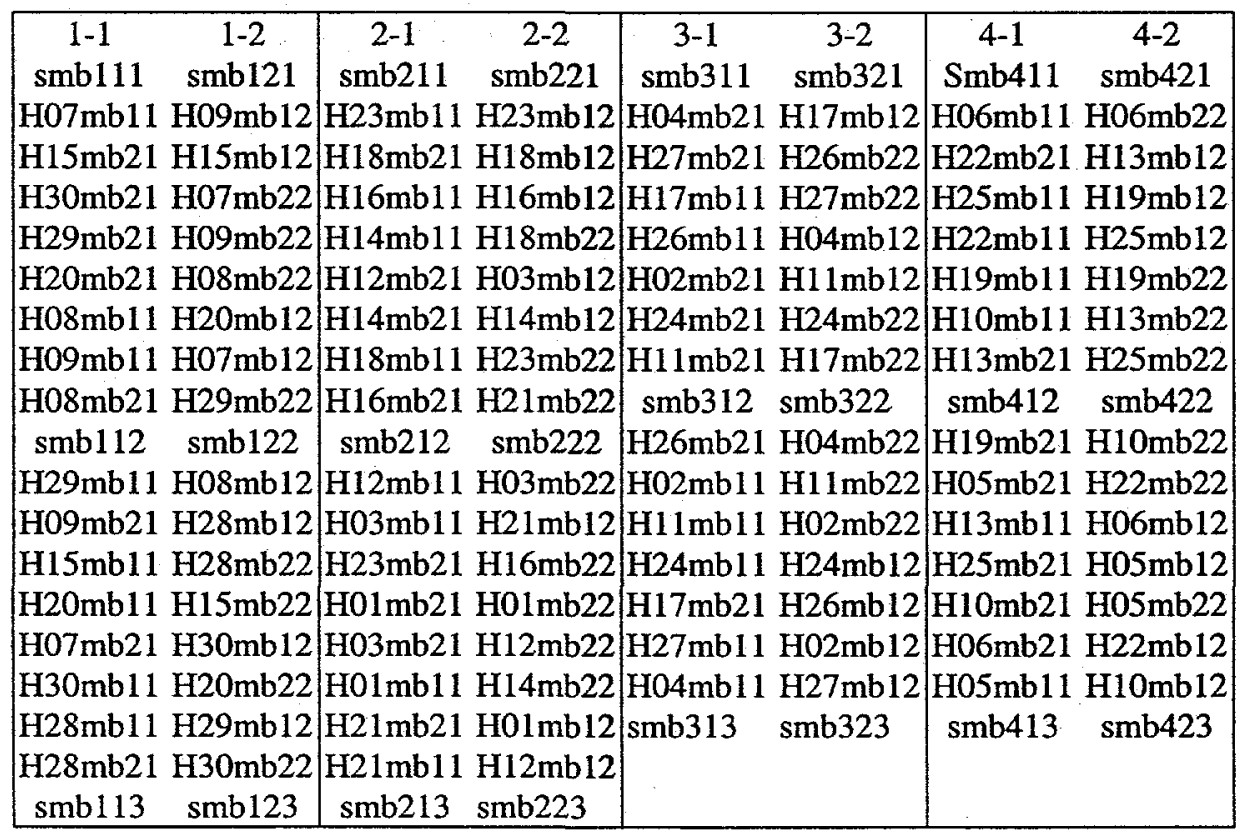


IC Calibration Blocks

The glass samples prepared by the potassium hydroxide dissolution method are to be analyzed using appropriately calibrated IC instrumentation. After the initial set of anion concentration measurements, the IC instrumentation is to be recalibrated and a second set of anion concentration measurements determined. A (randomized) plan for measuring these concentrations in the prepared samples is provided in Table 5.

In this table, the sample identifiers for the 30 glasses have been modified by the addition of a suffix ( $a$ " 1 " or a " 2 ") to indicate whether the measurement was made during the first or second (respectively) IC calibration block. Six samples of the LRM standard glass, each prepared via the potassium hydroxide method, have been added to this table. The identifiers for these samples begin with the letter " $\mathrm{s}$ " followed by the 2-letter preparation indicator ("kh"), then by a one-letter code indicating preparation order ("a" through "f"), then the two-digit IC block identifier, and finally, a number 1 through 3 for the three replicates per block.

Table 5: IC Blocks for the Fluoride Anion Measurements Using the Potassium Hydroxide (kh) Adsorption Method.

\begin{tabular}{|cc|cc|}
\hline $1-1$ & $1-2$ & $2-1$ & $2-2$ \\
skha111 & skha121 & skhd211 & skhd221 \\
H13kh11 & H22kh12 & H04kh11 & H25kh12 \\
H16kh11 & H02kh12 & H25kh11 & H08kh12 \\
H03kh11 & H13kh12 & H21kh11 & H12kh12 \\
H09kh11 & H19kh12 & H17kh11 & H01kh12 \\
H20kh11 & H26kh12 & H23kh11 & H23kh12 \\
H26kh11 & H16kh12 & H28kh11 & H21kh12 \\
H15kh11 & H10kh12 & H06kh11 & H04kh12 \\
skhb112 & H03kh12 & skhe212 & H29kh12 \\
H22kh11 & skhb122 & H01kh11 & skhe222 \\
H07kh11 & H07kh12 & H11kh11 & H28kh12 \\
H27kh11 & H27kh12 & H29kh11 & H11kh12 \\
H19kh11 & H05kh12 & H08kh11 & H14kh12 \\
H10kh11 & H24kh12 & H14kh11 & H18kh12 \\
H24kh11 & H09kh12 & H30kh11 & H17kh12 \\
H05kh11 & H20kh12 & H12kh11 & H06kh12 \\
H02kh11 & H15kh12 & H18kh11 & H30kh12 \\
skhc113 & skhc123 & skhf213 & skhf223 \\
\hline
\end{tabular}

\section{Concluding Comments}

In summary, this analytical plan identifies several ICP calibration blocks in Tables 3-4 as well as 10 preparation blocks in Table 2 and 4 IC blocks in Table 5 for use by the SRTC-ML. The sequencing of activities associated with each step in the analytical procedures has been randomized in the tables. The block size was selected based on the ability to complete the analysis within a single work shift. If for some reason the measurements are not conducted in the sequences presented in this report, a record should be made of the actual order used along with any explanative comments.

The analytical plan indicated in the preceding tables should be modified by the personnel of SRTC-ML to include any calibration check standards and/or other standards that are part of their routine operating procedures. 


\section{REFERENCES}

[1] Piepel, G. F., J. D. Vienna, and P. Hrma. 1999. Phase 1 Experimental Design for the INEEL HLW Glass Composition Variation Study, PNNL-SA-29594, Rev. 2, Pacific Northwest National Laboratory, Richland, Washington, January, 1999.

[2] Staples, B. A., D. K. Peeler, J. D. Vienna, B. A. Scholes, and C. A. Musick. 1999. The Preparation and Characterization of INTEC HAW Phase 1 Composition Variation Study Glasses, INEEL/EXT-98-00970, Rev. 1, Idaho National Engineering and Environmental Laboratory, Idaho Falls, Idaho, March, 1999.

[3] Edwards, T. B., D. K. Peeler, I. A. Reamer, G. F. Piepel, J. D. Vienna and H. Li. 1999. Phase $2 b$ Experimental Design for the INEEL Glass Composition Variation Study (U), WSRC-TR-99-00224, Revision 0, Westinghouse Savannah River Company, Aiken, South Carolina, March 30, 1999.

[4] Staples, B.A., B.A. Scholes, D.K. Peeler, L.L. Torres, J.D. Vienna, C.A. Musick, and B.R. Boyle. 2000. The Preparation and Characterization of INTEC Phase $2 b$ Composition Variation Study Glasses, INEEL/EXT-99-01322, February 2000. 